\title{
ORGANISATIONAL INNOVATIVENESS: THE ROLE OF LMX
}

\author{
JULIJA ŽAKEMO \\ MPhil., MBA
}

\begin{abstract}
Organisational innovativeness has been discussed as a paradigm industrywide (DeMiranda, et al., 2009) and as a national source of competitive advantage (Ludviga, 2012). Studies indicate that innovativeness might depend on leadership and leaders' capacities to establish right organisational climate. Current study investigates if the quality of relationship between the leaders and subordinates might influence the overall organisational innovativeness. The aim of the research is to test how the relationship between leaders and subordinates (measured by LMX scale, Graen, Uhl-Bien, 1995) impacts organisational innovativeness. The quantitative data were gathered via a structured survey within 80 large-size organizations with a total number of 405 respondents. To test the model, the hierarchical regression analysis was used.

The results showed that the quality of relationship between the leader and the subordinate plays a statistically significant role in organisational innovativeness. This study allows a more comprehensive understanding of LMX from the societal perspective. Implications for the business practitioners in Latvia and managerial literature on LMX and innovativeness are discussed.
\end{abstract}

Keywords: Latvia, leader-member exchange (LMX); organisational innovativeness, Latvian business context

JEL code: D01, D04, D21, D23

\section{INTRODUCTION}

Organisational innovativeness as a capability to produce new solutions, experiment, and engage in creative processes (Lumpkin and Dess, 2001) is emphasised by many authors as a fundamental element of survival and competitiveness for organisations (e.g. Little, et al., 2017; Anderson et al., 2014; Deschamps, 2009) and as a ground of regional development (Ludviga, 2012). Innovation and innovativeness are politically declared as a "survival skill" for organisations, nations, and humankind (Schumpeter, 1942) and recently has started to be regarded as a new development paradigm industry-wide (DeMiranda, et al., 2009). It is stated by the Innovation Policy Platform (IPP, 2013), developed by the Organisation for Economic Co-operation and Development (OECD) and the World Bank, that the innovation is crucial for long-term economic growth, as it fosters competitiveness, creates jobs, helps to address environmental and health issues, contributes to sustainable growth. Latvia ranks $33^{\text {rd }}$ in Global Innovation 
Index 2017, in comparison, Finland is ranked $8^{\text {th }}$ and Estonia $25^{\text {th }}$ (INSEAD, 2019). Thus, Latvia has perspectives for its growth and this of utmost actuality for Latvian economy.

Studies of organisational innovativeness suggest that innovativeness may have difficulties in application to reality (Wang and Ahmed, 2007; Riivari and Lämsä, 2014). This research has an attempt to reveal the eventual reasons for it. On the micro-level, organisations consist of individuals - employees and managers, teams, and interaction processes between them. According to promoters of micro-foundation movement, 'unwrapping' the individual-level factors (related to individuals) provides important starting point for analysis of macro-level (organisational) outcomes, such as organisational innovativeness, as individuals within the organisation have an influence on processes and routines, which, in turn, play a significant role in organisational outcomes (Felin, et al., 2015, p. 604).

The role of leadership in innovativeness has been shown to be important in previous studies (e.g. Buschens et al., 2013). Studies suggest that a leader has a role of a catalysator of change in the organisation (Trevino, et al., 2014). The attitudes and decision-making of top leadership resonate throughout the entire organisation (Kaptein, 2008; Trevino, et al., 2003). In the present study the focus is on a relational leadership, which represents micro-foundation of the organisation.

One of the most popular and useful approaches for understanding relational leadership and its influence on workplace outcomes is a leader-member exchange (LMX) theory (Yu, et al., 2018). This theory conceptualises leadership as a reciprocal process born in the interaction between leaders and followers (Graen and Uhl-Bien, 1995). Indeed, an important factor in the leadership process is a continuous and mutual relationship that a leader has with individual followers (Ferris, et al., 2009). Studies have found that high-quality relationship between both parties can affect both, the overall functioning of an organisation and employee personal well-being, so crucial to individuals' and organisations' productivity and effectiveness in working life (Graen and Uhl-Bien, 1995). Interesting, that according to Lord and Brown (2001) the employee perspective remains an underexplored source of understanding leadership processes. This study responds to this call.

In the following parts the key terms will be explained, methodology of the study will be discussed, the results will be introduced and analysed considering Latvia's business context so that it can be practically applied by business managers doing business in the Baltics.

\section{THEORETICAL BACKGROUND}

Leader - member exchange (LMX) theory describes how the leader and follower develop an interpersonal relationship over time, as two parties influence each other (Dansereau, Graen and Haga, 1975; Graen and Uhl-Bien, 1995). 
The terms "leader-member," "leader-follower," and "supervisor-subordinate or leader - employee" are used interchangeably, and it goes in line with Norvapalo (2014). LMX theory of leadership is stating that high-quality relationships form in-group circles which can be distinguished by high trust, commitment and loyalty and result in employee satisfaction, commitment, and empowerment (Harris, Wheeler and Kacmar, 2009). High LMX refers therefore to high quality of relationship, while low LMX means low quality of relationship among leader and follower.

According to Bennis (Bennis, 2007, p. 18) the phenomena of leadership can be explained as "grounded in a relationship". Rost (1995) distinguishes four essential elements of leadership, namely: 1) a relationship based on influence, 2) leaders' and followers' intention of enhancing such relationship, 3) the parties' intention of the changes, and 4) the presence of mutual purposes. Hollander (1995) was one of the first researchers who pointed on the two-way influence between leaders and followers, speaking of relationship of the parties involved. He has stated that a major component of the leader-follower relationship is the leader's perception of his or her self, relative to his or her followers, and how they in turn perceive the leader. Indeed, it has often stated throughout the history of leadership studies that leadership exists only in the interaction between the leaders and followers (Grint, 2000). The nature of interactions depends on the characteristics that everyone brings to the relationship, including their physical and psychological traits and disposes them to approach interpersonal situations in a certain way (Phillips and Bedeian, 1994).

Thus, in relational approach leadership is viewed as a relationship between parties, such as a leader and an employee. In particular, relational approach stresses processes rather than individuals, and view organisational members and leadership as made in processes (Fairhurst and Uhl-Bien, 2012). It is emphasised that this exchange process is constructing values, attitudes, and behaviours of the parties involved (Uhl-Bien, 2006; Hosking, 2007). Additionally, the contextual nature of leadership relationships, for example, a societal context (Osborn, et al., 2002), is acknowledged in relational approach. In general, it can be said that a switch from other approaches to relational one is a substantial since a focus has been changed from being the leader-centred to a leadership as a process of exchanges with the employees, and therefore both parties are viewed as contributors to the relationship, please see the figure 1 below. Moreover, Yukl, et al. (2009) and Yukl (2013) pointed out that within this process, both, leaders and followers are expected to behave ethically and concerning each other when fulfilling their responsibilities.

According to LMX theory, there exists an exchange of information (cognitions) and emotions among the parties, and it can be referred to as low and high LMX (Anand, et al., 2011; Liden, Sparrowe and Wayne, 1997; Sparrowe and Liden, 1997). High quality LMX relationships (high LMX) imply high quality of informational exchange; such relationships are based on mutual trust, 


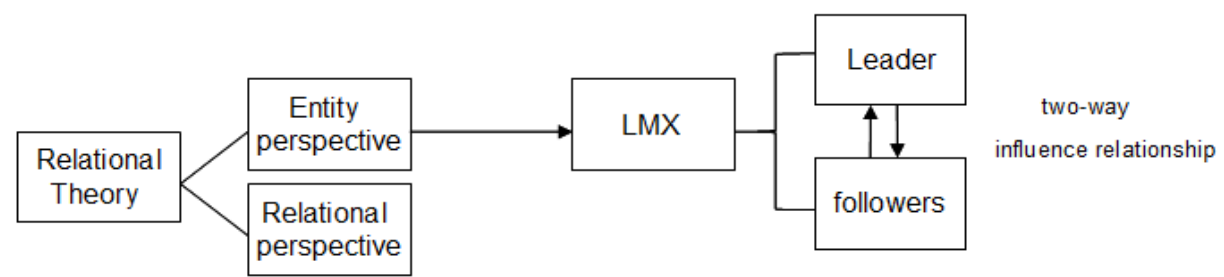

Figure 1. Perspectives of Relational leadership theory

Source: Uhl-Bien, 2006: 654, adapted with modifications

loyalty, respect, as well as emotional comfort and liking (Bauer and Green, 1996). High LMX are formed by a leader with the subordinates who constitute the "ingroup" circle (Dansereau, et al., 1975). According to social exchange theory, people tend to develop high-quality relationships based upon how frequently interaction occurs, as links become stronger (Dienesch and Liden, 1986). As a result, subordinates who are "in-group" followers are empowered with greater responsibilities, receiving more constructive attention from the leader, and these employees have bigger access to resources, they are given more freedom for performing their roles; relationships of this type exit the boundaries of the formal contract.

In the case of "out-group members", the quality of exchange of information and emotional support is low, there is generally lower level of trust; more control is used from the part of the leader and less initiative from the part of subordinate is observed. Such relationships indicate on low LMX (Graen and Uhl-Bien, 1995). Low-quality relationships put subordinates at a relative disadvantage in terms of job benefits and career progress (Fernandez and Vecchio, 1997). In low-quality relationships, members receive less access to the supervisor, resources, and more restricted information, potentially leading to dissatisfaction with their job, lower organizational commitment, and, further, employee turnover (Gerstner and Day, 1997). Low LMX relationships are characterized by economic exchanges based mainly on formal and tangible assets, such as employment contracts and payment (Dulebohn, et al., 2012).

Organisational innovativeness is organisational "overall internal receptivity to new ideas" and capability to experiment and engage in creative processes (Wang and Ahmed, 2004, p. 205). Innovativeness is a precondition for innovation (Walsh, et al., 2009; Utterback, 1994), which in turn, means "creating and delivering a new customer value to the marketplace” (Carlson \& Wimot, 2006). Innovativeness will be conceptualised as a multi-dimensional concept that consists of five dimensions: product, market, process, behavioural and strategic innovativeness (Wang and Ahmed, 2004).

According to Garcia and Calantone (2002), innovativeness is most frequently used as a measure of the degree of newness of an innovation. As to Adair (2009), to innovate means to bring to light something new, i.e. a new idea, a method or 
a product. He suggests that innovation as such is a relative concept, as what is innovative to one is a traditional way of doing things to another, but what is in the essence of innovation - the two aspects - to create 'new' ideas and to realise them. However, also creativity is considered to be the concept which explains the birth of novel and applicable ideas about products, practices, services, or procedures (Tierney and Farmer, 2011; Sterneberg and Lubart, 1999). Creativity scholars emphasise that creativity is a "potent competitive weapon" for organisations (Amabile, 1998, p. 87) and numerous studies show that cultivating employee creativity results in effective organisational outcomes, leading to a conclusion that a major objective for leaders in the 21st century is to be creative and to be able to enhance creativity (Aragon-Correa, et al., 2013; Dubkevics, 2015).

As it is argued that creative behaviour refers to the actions which result in generation of ideas that are both novel and useful (Sternberg and Frensch 2014; Lubart, 2008), it is an interrelated concept to that of innovation (Oldham and Cummings, 1996). Although the distinctions have been proposed, there remains a lack of general agreement between the researchers over what constitutes precisely creativity and when does the innovation begin.

According to Anderson, Potocnik and Zhou (2014), whereas creativity has been conceived as the generation of novel and useful ideas, innovation has been more referred to be both the production of creative ideas as the first stage, and their implementation as the second stage. Some literature in the field (Anderson, et al., 2014) however indicates that the boundaries between the concepts are not as clear. Paulus, et al., 2002, for example, observe creativity not just as the early stage of innovation process, but, because of its cyclical character - process of idea generation and its implementation - as a synonym to innovativeness suggesting that innovation and creativity can be used interchangeably (see also Basadur, 2004; Csikszentmihalyi, 2006). Following Zaltman, Duncan, and Holbek (1973), the ideas can be assessed on a continuum in terms of novelty and radicality, similarly, innovation may include novel and radical ideas, as well as ideas that are less novel and more incremental. An argument by Rank, et al. (2004) sheds the light in this debate - creativity, according to them, involves primarily intraindividual cognitive processes whereas innovation represents inter-individual social processes in the workplace.

This study applies Wang and Ahmed's (2004) consideration of organisational innovativeness. The authors have distinguished the following types of organisational innovativeness: product, process, market, behaviour, and strategic innovativeness. Product innovativeness refers to the newness of an organisation's products and services which are delivered to the market. Market innovativeness deals with new approaches of addressing the target audiences. Process innovativeness involves the usage of modernised or otherwise novel methods of production, managerial styles, and technologies that stimulate enhancement of production and its quality. Behaviour innovativeness means stimulation of 
creative potential of the employees, so that a so called 'climate for innovativeness' can occur. Last but not least, strategy innovativeness refers to the organization's capability to achieve its goals, being fast and flexible in the market and it indicates the leadership readiness to experiment, search for new and original solutions.

Governance of the organisation is underlined as an essential factor for the development of innovations in many studies (Damanpour and Wischnevsky, 2006; Drucker, 1998; Hill and Snell, 1988; Huse and Gabrielsson, 2008). It is argued (e.g. Yukl, 2002) that in general, leaders have a powerful source of influence on employees' work behaviours, and innovative behaviour is no exception.

High-quality exchanges with leaders provide employees with opportunities for skill development and self-improvement since supervisors give these employees their support, decision latitude, and freedom so that the employees can initiate, control, and carry out their tasks without excessive supervision (Sanders, et al., 2010). Subsequently, employees go beyond contractual expectations by performing spontaneous extra role behaviours (Basu and Green, 1997; Sparrowe and Liden, 1997; Wayne, Shore, and Liden, 1997). Moreover, when employees perceive that they have been fairly rewarded by their leader, they tend to react more innovatively in a higher job demand situation (Janssen, 2000). This occurs simply because employee view the existence of distribution equity with regards to the rewards thus being encouraged to engage in innovative work behaviour to a greater extend (Pucetaite, et al., 2016; Nie, Lamsa, and Pucetaite, 2018).

Indeed, high-quality LMX relationships are built on trust, respect, and mutual obligation (Brower, et al., 2000; Walumbwa, et al., 2010; Graen and Uhl-Bien, 1995), none of which would be present if a leader did not recognise and reward good performance and clarify expectations. Characteristics such as humbleness, authenticity and stewardship are mentioned as core qualities of a leader, clearly distinguishing most interpersonal leadership perspectives from more transactional and transformational approaches to leadership (van Dierendonck 2011; Van Wart 2012; Tummers and Knies 2013; Ricard, 2017). In this interpersonal perspective, the leader is a facilitator who builds relationships directly with the people in the organisation, providing a moral example and demonstrating that he/she is able to take responsibility for the whole organisation and its members (stewardship). Therefore, followers receiving goal clarification, recognition, and praise for their work feel a sense of obligation to their leader and are likely to experience higher quality relationships with them (Wayne, et al., 2002).

The current study tests on such control variables which are important to Latvian business context, for example the role of language being used in managersubordinate dyads in formation of organisational trust and innovativeness. As argued (Pucetaite, Lamsa, 2008; Alvesson, 2011; Kooskora, 2008), leadership is closely connected with the social culture. The LMX theory does not particularly emphasise the role of socio-cultural context which, in fact, can cause peculiarities of leadership process (Nie and Lamsa, 2015). Even though the leader is considered 
as somebody who exerts an impact on organisational culture (Alvesson, 2011) through social learning processes (Bandura, 1986), it has also been found that in different cultural contexts leadership can have different connotations (Pučètaitè and Lämsä, 2008; Alvesson, 2011; Harris and Carr, 2008). From this point of view, it is culture that shapes leadership. Following this line of argument, the current research considers the importance of specific socio - cultural context, in which the processes of leadership take place. The society in focus of this study, i.e. Latvia is a Baltic country that previously was a part of the Soviet Union. Since 2004 it is a member of NATO and the European Union. Latvia has a total population of less than 2 million. The main ethnic groups are Latvians at $57.7 \%$, followed by Russians at 29.6\%, Belarusian 4.1\%, Ukrainian 2.7\%, Polish 2.5\%, Lithuanian $1.4 \%$, and others at $\%$ (Central Statistic Bureau, 2017).

It can be argued that Latvia, like other countries which went through the change of socio-political formation, experienced the phenomena best described by the term 'brute capitalism' suggested by Young (2003). Looking back at the beginning of capitalistic relationship in our region, the words by Young (2003, p.14) can be used as an illustration:

"...all businesses [are placed] in some antisocial circumstance of cutthroat competition for survival. This free-market extremism pushes the logic of individual autonomy as far as it will go. [...] The goal is dominion over others; there [is] no need for fiduciary responsibilities. Self-interest without consideration of the whole set of circumstances is all [what is] needed..."

Indeed, in the analysis of the impact of rapid economic and political changes in Estonian society Kooskora (2008) demonstrated that rapid change of social values resulted in a low awareness of responsibility of a corporate world and in low trust of society towards business. The situation was similar in other Baltic countries. Huettinger (2008) study based on Hofstede model (2003) showed that all cultural dimensions among the three Baltic Republic score very similarly. He also argues that "in many cases, incompetent managers led new companies into failure and employees into unemployment”. As suggested by a study that explored expectations towards business ethics on the basis of social representations of the concept (Bulatova, 2016) in the period from 2003 to 2005, business ethics in Latvia was associated with "unnecessary waste of time", and the word combination per se did not make any sense. As noticed by Mole (2003) citizens of Latvia and Lithuania 'know very well about unjustified and unexpected hardships of economic transition'. Pučètaitè (2014) points out that it is a heritage of a soviet past in a post-socialistic context that explains a lack of responsibility, low trust and opportunistic behaviour in economic relationships. Analysing trust towards political institutions in Lithuania, Pučètaitè and Lämsä (2008) argue that in post - socialistic societies leaders are expected to be confident and decisive while the followers have to show obedience. However, cases of Enron, World.com, Apple, Solomon Brothers and many others shake the questions of moral grounds of capitalism. Therefore, the call for a responsible leader seems to be an actual 
topic not only for Latvian society. It can also be argued that it is not a political formation as such, but rather a concrete leadership practice, which matters when one poses a question of ethical or unethical leadership. This study draws attention that organisational innovativeness and organisational trust can be a consequence of concrete relationships which occur between leaders and followers, and that innovativeness and trust can be enhanced when high quality relationship takes place, i.e. ethical concerns of the parties involved are met and leaders realise their role in this process.

There exists however already a theoretical background to assume that relationship leadership tested by LMX, has an impact on organisational innovativeness and innovativeness in particular (e.g. Basu and Green, 1997; Pucetaite, 2014). As to Dick, et al., "leaders act through their followers and a leader's behaviour is successful because it is translated into followers' actions" (Dick, et al., 2007, p. 134). By extension, it is reasonable to expect that leaders who are keen in innovative decisions will likely channel their own aspirations towards producing innovative outcomes through mobilizing followers to produce such outcomes.

Hence, LMX is discussed here as an indication on the leader's capability to create conditions for organisational innovativeness. It is hypothesised that leaders who form high LMX are more likely to encourage innovativeness among their followers compared to low-LMX leaders. Therefore, it was decided to test the existing model (Pucetaite, 2014) and the hypothesis that LMX has

\section{a statistically significant effect on organisational innovativeness.}

According to De Souza, individual enters relationships under certain conditions of the context that restrict or enable reaction possibilities (De Souza, 2014), therefore broad and nuanced understanding of a phenomenon can be reached only when taking into account context factors. For example, Huy identified language and tenure as socio-emotional factor having important implication for the success and positive organisational level outcomes (Huy, 2011). This research follows Spector and Brannick (2011) who recommend avoiding using demographic variables only as proxies for variables if they are of a real interest. They suggest that context variables should be directly investigated since they can explain the reasons for observed results (Spector and Brannick, 2011).

\section{METHODOLOGY OF THE STUDY}

An electronic survey was sent to employees of 80 large size organisations of Latvia. Since the model is tested in the situation of Latvian business context, it was decided to quantitatively test the model on the sample of large-sized business of Latvia which constitutes 236 enterprises, as to the year 2016 (Central Statistics Bureau of Latvia, 2016). According to Investorwords (2019) online resource, it is a company which has a turnover of more than $£ 5.75 \mathrm{~m}$ or employs more 
than 250 staff. Central Statistics Bureau (CSB, 2019) data for 2017 suggest that there were 93775 economically active enterprises in Latvia, out of which Micro businesses are $86,2 \%$, Small enterprises constitute $11,1 \%$, medium $-2,3 \%$, and Big ones - are counted just for $0,4 \%$.

Assuming continuous data, the researcher should determine if a categorical variable will play a primary role in data analysis (Barlett, et al., 2001). If so, the categorical sample size formulas should be used. Assuming the alpha level a priori at .05 level, as well as keeping in mind that a seven-point Likert scale will be applied and having set the level of acceptable error at 3\%, the estimated standard deviation is 1.167 . In that case for a population of 236 , the required sample size is 118 . However, since this sample size exceeds $5 \%$ of the population $\left(1,679^{*} .05=84\right)$, Cochran's (1977 quoted in Barlett, et al., 2001) correction formula should be used to calculate the final sample size. Following the calculations, 78 large-size companies is a sufficient sample size for this research.

The questionnaire consisted of three parts:

1. demographical part, measuring language spoken between the parties, respondents' belonginess to a generation, gender, education, status, tenure of experience within the same organisation, and industry in which the company operates;

2. the LMX scale (Graen and Uhl-Bien, 1995),

3. the Organisational innovativeness measurements instrument (Wang and Ahmed, 2004).

Measurement of the independent variable: LMX was measured by a 7-statement questionnaire (Graen and Uhl-Bien, 1995) applying a five-point Likert scale (1 meaning "totally disagree" and 5 "totally agree").

Measurement of the dependent variable: Organizational innovativeness in turn, was measured by Wang and Ahmed's (2004) questionnaire consisting of 20 questions, covering five dimensions, namely: product (4 items), market (4 items), strategic (4 items), process (4 items), and behavioural innovativeness (4 items), altogether the scale has 20 questions. Some of the statement examples are "new products and services in our company often take us up against new competitors", "in our company, we tolerate individuals who do things in a different way." Again, a 7-point Likert scale is applied for answering the questions ( 1 = strongly disagree, 7 = strongly agree). The third, sixth, ninth and nineteenth questions are reverse questions in the scale.

Mumford and Licuanan (2004) concluded that one cannot expect existing leadership models which are developed to predict performance in routine settings, to be entirely applied to the leadership of innovative individuals. There are various discussions as to validity of perception of innovativeness, and there is an argument that such measuring does not reflect the real status of the organisation's innovativeness, while others state this being an adequate technique because it reflects comparative estimation of innovativeness in 
connection to other companies in the field and thus reflects critical views and societal comprehension of the phenomena within the company. It is supported by the studies by Nie and Lamsa (2015), Pucetaite, et al. (2016).

Table 1

Measurement of the research variables and composition of the survey

\begin{tabular}{|l|l|l|l|}
\hline \multicolumn{1}{|c|}{ Variable } & \multicolumn{1}{c|}{ Survey items } & \multicolumn{1}{c|}{ Measurement scale } & \multicolumn{1}{c|}{ Reference } \\
\hline $\begin{array}{l}\text { Organisational } \\
\text { Innovativeness }\end{array}$ & $\begin{array}{l}\text { Section 1: } \\
\text { statements 1-20 }\end{array}$ & 7-point Likert scale & $\begin{array}{l}\text { 20-item scale (Wang, } \\
\text { Ahmed, 2004) }\end{array}$ \\
\hline $\begin{array}{l}\text { Leader-member } \\
\text { exchange (LMX) }\end{array}$ & $\begin{array}{l}\text { Section 3: } \\
\text { statements 1-7 }\end{array}$ & 5-point Likert scale & $\begin{array}{l}\text { 7-item scale (Graen and } \\
\text { Uhl-Bien, 1995) }\end{array}$ \\
\hline Context factors & Section 4: & Male/female \\
\hline & gender & Secondary/college/bachelor/master/doctoral \\
\hline & education & Years (belonginess to a generation) \\
\hline & age & Specialist/manger/top manager \\
\hline & status & Both native/native vs foreign/both foreign \\
\hline & language & \multicolumn{2}{l}{} \\
\hline
\end{tabular}

The questionnaire was translated from English to Latvian and then back to English, i.e. a translation and back-translation method was used, which is stated to ensure the reliability and validity of the instrument (Brislin, 1970).

\section{RESULTS}

As seen in Table 2 below, reliability tests of the scales of LMX and those of organisational innovativeness has yielded high Cronbach's alphas (coefficients are above 0.7 ), indicating on high internal consistency of the scales and meaning that the data can be used for further analysis.

Table 2

Cronbach's Alfa and Descriptive statistics of the research constructs $(n=405)$

\begin{tabular}{|l|l|l|l|l|l|l|}
\hline \multicolumn{1}{|c|}{ Variable } & $\begin{array}{c}\text { No of items } \\
\text { per scale }\end{array}$ & $\begin{array}{c}\text { Cronbach's } \\
\text { Alfa }\end{array}$ & Mean & $\begin{array}{c}\text { Std. } \\
\text { Deviation }\end{array}$ & $\begin{array}{c}\text { Mini- } \\
\text { mum }\end{array}$ & $\begin{array}{c}\text { Maxi- } \\
\text { mum }\end{array}$ \\
\hline LMX & 7 & 0.88 & $3.69^{* *}$ & 0.67 & 1.00 & 5.00 \\
\hline Innovativeness & 20 & 0.80 & $5.18^{*}$ & 0.71 & 1.90 & 6.60 \\
\hline Product innovativeness & 4 & 0.84 & 5.30 & 0.94 & 2.50 & 7.00 \\
\hline Market innovativeness & 4 & 0.75 & 5.22 & 0.85 & 1.00 & 6.75 \\
\hline Process innovativeness & 4 & 0.79 & 5.24 & 0.82 & 1.00 & 6.75 \\
\hline Strategic innovativeness & 4 & 0.75 & 5.18 & 0.81 & 2.25 & 6.75 \\
\hline Behavioural innovativeness & 4 & 0.88 & 4.97 & 0.97 & 1.00 & 7.00 \\
\hline
\end{tabular}

** 5-point Likert scale

* 7-point Likert scale 
Organisational innovativeness of Latvian large-size organisations is perceived as high (significantly above average in 7-point scale) by employees. The highest component is product innovativeness, followed by process innovativeness, whereas, the lowest evaluation is assigned to behavioural and strategic innovativeness.

To test the hypothesis of the study, data was analysed using hieratical linear modelling since it allows specifying a fixed order of entry for variables in order to test the effects of certain predictors independently of the influence of other factors. Table 3 below summarises the results of the regressions of the test score on various set of regressors. Trust and Innovativeness were treated as onedimensional constructs to avoid multicollinearity which may cause problems to regression analysis. Table 3 below presents the summary of hierarchical linear regression.

Table 3

Summary of the results of hierarchical regression

\begin{tabular}{|c|c|c|c|c|c|c|c|c|}
\hline Variable & Model 1 & Model 2 & Model 3 & Model 4 & Model5 & Model 6 & Model 7 & Model 8 \\
\hline Industry Sect 2 & $0.47^{* * *}$ & $0.44^{* * *}$ & $0.24^{*}$ & $0.27^{*}$ & $0.24^{*}$ & $0.23^{*}$ & $0.23^{*}$ & 0.18 \\
\hline Industry Sect 3 & $0.49^{* * *}$ & $0.34^{* *}$ & 0.10 & 0.08 & 0.05 & 0.03 & 0.03 & 0.08 \\
\hline Industry Sect 4 & $0.33^{*}$ & 0.18 & 0.09 & 0.13 & 0.10 & 0.09 & 0.10 & 0.13 \\
\hline Industry Sect 5 & 0.05 & -0.15 & -0.21 & -0.15 & -0.16 & -0.15 & -0.15 & -0.16 \\
\hline Industry Sect 6 & $0.60^{* * *}$ & $0.30^{*}$ & 0.12 & 0.15 & \begin{tabular}{|l|}
0.16 \\
\end{tabular} & 0.14 & \begin{tabular}{|l|}
0.12 \\
\end{tabular} & 0.11 \\
\hline Industry Sect 7 & $0.31^{*}$ & 0.18 & 0.15 & 0.19 & 0.18 & 0.18 & 0.18 & 0.19 \\
\hline LMX & & $0.56^{* * *}$ & $0.30^{* * *}$ & $0.33^{* * *}$ & $0.34^{* * *}$ & $0.34^{* * *}$ & $0.35^{* * *}$ & $0.36^{* * *}$ \\
\hline Gender (male) & & & -0.01 & 0.00 & 0.01 & 0.01 & 0.01 & -0.03 \\
\hline Generation Y & & & & -0.06 & -0.06 & -0.07 & -0.07 & -0.08 \\
\hline Generation X & & & & 0.09 & 0.09 & 0.01 & 0.01 & 0.01 \\
\hline Generation BB & & & & $0.26^{*}$ & $0.26^{*}$ & 0.16 & 0.16 & 0.18 \\
\hline $\begin{array}{l}\text { Status (mid- } \\
\text { manager) }\end{array}$ & & & & & -0.12 & -0.14 & -0.13 & $-0.19^{*}$ \\
\hline $\begin{array}{l}\text { Status (top- } \\
\text { manager) }\end{array}$ & & & & & -0.11 & -0.15 & -0.14 & -0.24 \\
\hline $\begin{array}{l}\text { Tenure ( } 2 \text { to } \\
5 \text { years) }\end{array}$ & & & & & & -0.02 & -0.02 & 0.00 \\
\hline $\begin{array}{l}\text { Tenure } \\
\text { (15 plus years) }\end{array}$ & & & & & & $0.23^{* *}$ & $0.23^{* *}$ & $0.25^{* * *}$ \\
\hline Language 2 & & & & & & & 0.06 & 0.05 \\
\hline Language 3 & & & & & & & 0.09 & 0.10 \\
\hline Education 3 & & & & & & & & -0.08 \\
\hline Education 4 & & & & & & & & $0.30^{* * *}$ \\
\hline (Constant) & 4.86 & 2.91 & 1.84 & 1.87 & 1.86 & 1.90 & 1.82 & 1.83 \\
\hline
\end{tabular}




\begin{tabular}{|l|l|l|l|l|l|l|l|l|}
\hline \multicolumn{1}{|c|}{ Variable } & Model 1 & Model 2 & Model 3 & Model 4 & Model5 & Model 6 & Model 7 & Model 8 \\
\hline $\begin{array}{l}\text { Adjusted R } \\
\text { Square }\end{array}$ & 0.06 & 0.33 & 0.46 & 0.47 & 0.47 & 0.48 & 0.48 & 0.53 \\
\hline $\begin{array}{l}\text { R Square } \\
\text { Change }\end{array}$ & 0.08 & 0.27 & 0.00 & 0.01 & 0.00 & 0.01 & 0.00 & 0.05 \\
\hline F Change & 5.43 & 162.94 & 0.02 & 3.46 & 1.42 & 5.28 & 0.78 & 20.84 \\
\hline Sig. F Change & 0.00 & 0.00 & 0.89 & 0.02 & 0.24 & 0.01 & 0.46 & 0.00 \\
\hline
\end{tabular}

${ }^{*} \mathrm{p}<0.05 ;^{* *} \mathrm{p}<0.01$; $^{* *} \mathrm{p}<0.001$

Adjusted R Square tells how "good" the model is at predicting or explaining the values of dependent variable (Stock and Watson, 2012, p. 227).

Since the industry factor is above organisational context and cannot be controlled by a leader, industry was not the object of interest in this research and is treated as a control variable. In the first step control variables (Industry dummies) were inserted (see Model 1). Industry sector dummies where created with Sector 1 as baseline. LMX was entered as independent variable. Data in the Table 3 (Model 1) show that Industry factor alone is able to explain only $6 \%$ of organisational innovativeness (adjusted $\mathrm{R}^{2}=0.06$ ). Interestingly that Sector 6 named 'other industries', which include art, entertainment, health and social activities, and education, appeared to report the highest innovativeness, followed by sector 2 'electricity, gas, water supply and waste management' and sector 3 'manufacturing and construction'. Sector 5 'service' has no impact on organisational innovativeness.

When LMX is added (Model 2), the model explains 33\% of organisational innovativeness (adjusted $\mathrm{R}^{2}=0.33$ ), what is consistent with the Hypothesis of the study (LMX has a statistically significant impact on organisational innovativeness).

Adding the variables of contextual factors, it was tested weather contextual factors are statistically significant moderators in LMX and innovativeness relationship. Model 3 particularly shows that gender has no additional effect on innovativeness (adjusted $\mathrm{R}^{2}=0.46$; it is the same as in the previous model and change is not significant). Model 4 shows the effect of employee's or manager's age (measured as generation) and can explain additional $1 \%$ of organisational innovativeness (adjusted $\mathrm{R}^{2}=0.47$; Sig. F Change $=0.02$ ) and this change is significant. Thus, age has an impact on innovativeness, and especially "Baby Boomers" show a significant relationship with dependent variable.

Model 5 shows the effect of status and explains the same $47 \%$ of organisational innovativeness (adjusted $\mathrm{R}^{2}=0.47$ ), thus status does not add any power. However, the tenure (Model 6) shows additional effect on organisational innovativeness (adjusted $\mathrm{R}^{2}=0.48$; Sig. F Change $=0.01$ ). Moreover, respondents with tenure more than 15 years show significant effect on dependent variable $(B=0.23$; sig $=0.007)$. Language of communication (Model 7) does not add any explanatory 
power to the model (adjusted $\mathrm{R}^{2}=0.48$; Sig. F Change $=0.46$ ). However final model which adds education (Model 8) exhibits additional 5\% explanatory power (adjusted $\mathrm{R}^{2}=0.53$; Sig. $\mathrm{F}$ Change $=0.00$ ). Model 8 therefore explains $53 \%$ of organisational innovativeness.

Hence, the results of hierarchical multiple regression analysis support the main hypothesis. The correlation between the LMX and organisational innovativeness was found to be $0.521, \mathrm{p}<0.001$.

\section{CONCLUSIONS}

Organisational innovativeness of Latvian large-size organisations is perceived by the employees as high (all components evaluated significantly above average). Latvian organisations are evaluated to be more active in product and process innovativeness, but less active in behavioural and strategic innovativeness.

Industry sector in which organisation operates has statistically significant, but still low impact on organisational innovativeness (it accounts only for $6 \%$ of organisational innovativeness). Sector named 'other industries', which include art, entertainment, health and social activities, and education, appeared to report the highest innovativeness, followed by 'electricity, gas, water supply and waste management' and 'manufacturing and construction'. Service sector has no impact on organisational innovativeness.

Leader-member exchange (LMX) quality is essential for increasing organisational innovativeness (it accounts for $27 \%$ to $31 \%$ of organisational innovativeness of Latvian large-size organisations), thus it serves as microfoundation of organisational innovativeness. The strongest effect of LMX is revealed in the case of behaviour innovativeness, followed by its effect on process innovativeness, but the weakest effect was found on product innovativeness. LMX alone has no significant effect on strategic and product innovativeness. This shows that the leader through the relationship with the subordinate can directly influence the behaviour and organisation of the processes but cannot directly influence the strategic and product innovativeness.

To summarise, as innovativeness corresponds to an organisational capability for generation of new and useful ideas, certain atmosphere of trust should take place, where knowledge and idea sharing can occur. The role of a leader who is able to develop high quality relationships, which are based on mutual reciprocity, respect, loyalty, and trust, is argued to be crucial in this process as quality of dyadic relationship echoes throughout the entire organisation. Current research contributes to knowledge and understanding of the LMX theory by contextualizing it in Latvian setting.

In line with the conclusions, the following is recommended for leaders of large-size organisations: Leaders should 'vision' innovativeness: discussions on the matters of innovativeness should be raised within the organisations. 
The leaders of the organisations should enhance the meaning of innovativeness and provide support for initiatives of the employees with their innovative solutions. For example, groupwork and innovativeness (creativity) workshops should take place within the organisations, even if the direct tasks of the employees are not connected with the workshops' capacity development, but such activities generally enhance the level of innovativeness, and participation in such workshops should be incorporated in annual evaluations.

Leaders should ensure high quality relationship with subordinates, which primarily is based on trust. Leader who are able to sustain high quality relationships, which is based on mutual reciprocity, respect, loyalty, and trust is crucial in this process as quality of dyadic relationship echoes throughout the organisation. Leaders should also trust their employees: delegation also should include trusting, employees should be able to voice their concerns, communication should be open and transparent throughout the organisation. Employees should not be afraid to make mistakes to a reasonable extent. When concrete rationalised solutions or problems are raised by the employees, it is of utmost importance to give a constructive feedback, react, and, if possible, find the ways of incorporating new ideas into organisational decisions.

Leaders should be trusted and act as role-models: managers should act as creative and innovative personalities, one whom employees can trust. Leaders should also monitor the innovativeness: Recognition of innovative solutions should be linked to effectiveness and efficiency. This also includes allowing for mistakes and recognition of moral choice decisions.

Leaders should take into consideration organisational context in which they operate, for example gender distribution of the workforce; age of employee, tenure and even use of language (native or not) in their communication, since this impacts how relationship with subordinates will result in innovativeness.

\section{REFERENCES}

1. Adair, J., 2009. Effective teambuilding: How to make a winning team. Pan Macmillan.

2. Amabile, T. M., 1998. How to kill creativity. Harvard Business Review, September/ October, pp. 77-87.

3. Anand, S., Hu, J., Liden, R. C. \& Vidyarthi, P. R., 2011. Leader-member exchange: Recent research findings and prospects for the future, 311-325. In A. Bryman (Ed.) The Sage Handbook of Leadership. London: Sage Publications.

4. Anderson, N., Potočnik, K. \& Zhou, J., 2014. Innovation and Creativity in Organizations: A State-of-the-Science Review and Prospective Commentary. Journal of Management, 40 (5), 1297-1333. Alvesson, 2011.

5. Aragón-Correa, J. A., Martín-Tapia, I., Hurtado-Torres, N. E., 2013. Proactive environmental strategies and employee inclusion: The positive effects of information sharing and promoting collaboration and the influence of uncertainty. Organization \& Environment, 26(2), 139-161. 
6. Bandura, A., 1986. Social foundation of thougB34:B41ht and action. Englewood Cliffs, New Jersey: Prentice-Hall.

7. Basadur, M., 2004. Leading Others To Think Innovatively Together: Creative Leadership. The Leadership Quarterly, 15, pp. 103-121.

8. Barlett, J. E., Kotrlik, J. W., Higgins, C. C., 2001. Organizational research: Determining appropriate sample size in survey research. Information Technology, Learning, and Performance Journal, Spring iss., pp. 43-50.

9. Basu, R., Green, S. G., 1997. Leader-member exchange and transformational leadership: an empirical examination of innovative behaviors in leader-member dyads. Journal of Applied Social Psychology, 27 (6), pp. 477-99.

10. Bauer, T. N., Green, S. G., 1996. Development of leader-member exchange: A longitudinal test. Academy of management journal, 39(6), pp. 1538-1567.

11. Bennis, W., 2007. The Challenges of Leadership in the Modern World. American Psychological Association. Vol. 62, (1), 2-5.

12. Brislin, R. W., 1970. Back - Translation for Cross - Cultural research. Journal of Cross-Cultural Psychology. September 1(3), 185-216.

13. Bulatova, J., 2016. Morality as an Index of Mental Health of the Organisation: Building a model of healthy leadership. In: M. C. C. Arruda and B. Rok (Ed.) Understanding Ethics and Responsibilities in a Globalising World. Springer: Switzerland.

14. Buschgens, T., Bausch, A., Balkin, D. B., 2013. Organisational Culture and Innovation: A Meta-Analytic review. Journal of Product Innovation Management 30 (4), pp. 763-781.

15. Carlson C. R., Wilmot, W. W., 2006. Innovation: The Five Disciplines for Creating What Customers Want. Random House, New York.

16. CSB, 2017. Employment in different sectors in Latvia on the second quarter of 2017. Available at: http://www.csb.gov.lv/en/statistikas-temas/occupiedposts-and-jobvacancies-paid-working-hours-key-indicators-30604.html; [assessed: 09.09.2017]. Central Statistic Bureau, 2017).

17. Damanpour, F., Wischnevsky, J. D., 2006. Research on innovation in organizations: Distinguishing innovation-generating from innovation-adopting organizations. Journal of engineering and technology management, 23(4), 269-291.

18. Dansereau, F. Jr., Graen, G. and Haga, W. J., 1975. A vertical dyad linkage approach to leadership within formal organization: a longitudinal investigation of the role making process, Organizational Behavior \& Human Performance. 13(1), pp. $46-78$.

19. DeMiranda, P. C., Aranha, J. A. S., Zardo, J., 2009. Creativity: people, environment and culture, the key elements in its understanding and interpretation. Science and Public Policy, 36(7), pp. 523-535.

20. Deschamps, J-P., 2009. Innovation Leaders: How Senior Executives Stimulate, Steer and Sustain Innovation. John Wiley \& Sons.

21. De Souza, D. E., 2014. Culture, context and society: The underexplored potential of critical realism as a philosophical framework for theory and practice. Journal of Social psychology, 17, pp. 141-151.

22. van Dierendonck, D., Patterson, K., 2015. Compassionate love as a cornerstone of servant leadership: An integration of previous theorizing and research. Journal of Business Ethics, 128(1), pp. 119-131.

23. Dienesch, R. M., Liden, R. C., 1986. Leader-Member Exchange Model of Leadership: A Critique and Further Development. The Academy of Management Review, 11(3), pp. 618-634. 
24. Drucker, P. F., 1998. The discipline of innovation. Leader to Leader, 1998(9), $13-15$.

25. Dubkevics, L., 2015. Interrelation between organizational culture and climate for creativity in state theatres in Latvia. Journal of Business Management, (9).

26. Dulebohn, J. H., Bommer, W. H., Liden, R. C., Brouer, R. L., Ferris, G. R., 2012. A Meta-Analysis of Antecedents and Consequences of Leader-Member Exchange: Integrating the Past With an Eye Toward the Future, Journal of Management. Vol. 38, pp. 1715-1759.

27. Fairhurst, G. T., Uhl-Bien, M., 2012. Organizational discourse analysis (ODA): Examining leadership as a relational process. The Leadership Quarterly, 23(6), pp. 1043-1062, Fairhurst and Uhl-Bien, 2012.

28. Felin, T., Foss, N. J. \& Ployhart, R. E., 2015. The Microfoundations Movement in Strategy and Organization Theory. The Academy of Management Annals, 9(1), pp. 575-632.

29. Ferris, G. R., Liden, R. C., Munyon, T. P., Summers, J. K., Basik, K. J., Buckley, R. M., 2009. Relationships at Work: Toward a Multidimensional Conceptualization of Dyadic Work Relationships. Journal of Management. 35 (6), pp. 1379-1403.

30. Garcia, R., Calantone, R., 2002, A critical look at technological innovation typology and innovativeness terminology: a literature review. The Journal of Product Innovation Management, Vol. 19, pp. 110-132.

31. Gerstner, C. R., Day, D. V., 1997. Meta-Analytic review of leader-member exchange theory: Correlates and construct issues. Journal of applied psychology, 82(6), pp. 827-844.

32. Graen, G. B., Uhl-Bien, M., 1995. Relationship-Based Approach to Leadership: Development of Leader-Member Exchange (LMX) Theory of Leadership over 25 Years: Applying a Multi-Level Multi-Domain Perspective. Leadership Quarterly, 6, pp. 219-247.

33. Grint, 2000

34. Harris, S., Carr, C., 2008. National cultural values and the purpose of businesses. International Business Review, 17(1), pp. 103-117.

35. Harris, K. J., Whealer, A. R., Kacmar, M., 2009. Leader-member exchange and empowerment: Direct and interactive effects on job satisfaction, turnover intentions, and performance. The Leadership Quarterly, 20(3), pp. 371-382.

36. Hollander, E. P., 1995. Ethical challenges in the leader-follower relationship. Business Ethics Quarterly, 5(1), pp. 55-65.

37. Hosking, D. M., 2007. Not leaders, not followers: A post-modern discourse of leadership processes. Follower-centred perspectives on leadership: a tribute to the memory of James R. Meindl, Information Age, Charlotte, NC, 243-263.

38. Hill, C. W., Snell, S. A., 1988. External control, corporate strategy, and firm performance in research-intensive industries. Strategic management journal, 9(6), pp. 577-590.

39. Hofstede, G., 2003. What is culture? A reply to Baskerville. Accounting, Organizations and Society, Vol. 28, pp. 811-813.

40. Huettinger, M., 2008. Cultural dimensions in business life: Hofstede's indices for Latvia and Lithuania. Baltic Journal of Management, 3(3), pp. 359-376.

41. Huy, Q. N., 2011. How middle managers' group-focus emotions and social identities influence strategy implementation. Strategic Management Journal, 32(13), pp. 1387-1410. 
42. Innovation Policy Platform (IPP), 2013. Available at: https://www.fosteropenscience.eu/content/innovation-policy-platform-ipp, [accessed: 12.11.2014].

43. Janssen, O., Yperene, N. W. V., 2004, Employees' Goal Orientations, The Quality Of Leader-Member Exchange, And The Outcomes Of Job Performance And Job Satisfaction, Academy of Management Journal, 47(3), pp. 368-384.

44. Kaptein, M., 2008. Developing and testing a measure for the ethical culture of organisations; the corporate ethics virtue model. Journal of Organisational Behaviour, 29(7), pp. 923-947.

45. Kooskora, M., 2008. Understanding Corporate Moral Development in the Context of Rapid and Radical Changes. The Case of Estonia. Academic dissertation defended in University of Jyväskylä.

46. Liden, R. C., Sparrowe, R. T., \& Wayne, S. J., 1997. Leader-Member Exchange Theory: The Past and Potential for the Future. In. G. R. Ferris (Ed.), Research in personnel and human resources management (Vol. 15, pp. 47-120). Greenwich, CT: JAI Press.

47. Lord, R. G., \& Brown, D. J., 2001. Leadership, values, and subordinate selfconcepts. The Leadership Quarterly, 12(2), pp. 133-152.

48. Ludviga, I., 2012. National Identity and Culture Grounded Competitive Advantage: Innovative Business Models. Conference paper. 7th International Scientific Conference "Business and Management". May 10-11, 2012. Vilnius, Vilnius Gediminas Technical University.

49. Lumpkin, G. T., Dess, G. G., 2001. Linking two dimensions of entrepreneurial orientation to firm performance: The moderating role of environment and industry life cycle. Journal of Business Venturing, 16, pp. 429-451.

50. Mole, J., 2003. Mind your Manners: Business Cultures in Europe - Managing Business Cultures. Nicholas Brealey Publishing: London.

51. Nie, D., Lämsä, A. M., 2015. The leader-member exchange theory in the Chinese context and the ethical challenge of guanxi, Journal of Business Ethics, 128 (4), pp. 851-861.

52. Nie, D., Lämsä, A. M., Pučètaitè, R., 2018. Effects of responsible human resource management practices on female employees' turnover intentions. Business Ethics: A European Review, 27(1), pp. 29-41. Nie and Lamsa (2015).

53. Nie, Lamsa, and Pucetaite, 2018.

54. Norvapalo, K., 2014. The Quality and Development of the Leader-Follower Relationship and Psychological Capital. A Longitudinal Case Study in a Higher Education Context. University of Jyvaskyla.

55. Oldham, G. R., Cummings, A.,1996. Employee creativity: Personal and contextual factors at work. Academy of management journal, 39(3), pp. 607-634.

56. Osborn, R. N., Hunt, J. G., Jauch, L. R., 2002. Toward a contextual theory of leadership. Leadership Quarterly, 13, pp. 797-837.

57. Paulus, P. B., Putman, V. L., Dugosh, K. L., Dzindolet, M. T., Coskun, H., 2002. Social and cognitive influences in group brainstorming: Predicting production gains and losses. European review of social psychology, 12(1), pp. 299-325.

58. Pučètaitè, R., Novelskaitè, A., Lämsä, A. M., Riivari, E., 2016. The relationship between ethical organisational culture and organisational innovativeness: Comparison of findings from Finland and Lithuania. Journal of business ethics, 139(4), pp. 685-700.

59. Pučètaite, R., 2014. Stimulating organizational innovativeness through ethical leadership practices: the mediating role of organizational trust. $19^{\text {th }}$ International 
Scientific Conference; Economics and Management 2014, ICEM, Latvia. Procedia - Social and Behavioral Sciences 156, pp. 231-235.

60. Pučètaitè, R., Lämsä, A. M., 2008. Developing organizational trust through advancement of employees' work ethics in a post-socialist context. Journal of Business Ethics 82, pp. 325-337.

61. Rank, J., Pace, V. L., Frese, M., 2004. Three avenues for future research on creativity, innovation, and initiative. Applied psychology, 53(4), pp. 518-528.

62. Riivari, E., Lämsä, A. M., 2014. Does it pay to be ethical? Examining the relationship between organisations' ethical culture and innovativeness. Journal of Business Ethics, 124(1), pp. 1-17.

63. Rost, J. C., 1995. Leadership: A Discussion about Ethics. Business Ethics Quarterly, 5 (1), pp. 129-142.

64. Schumpeter, J., 1942. Capitalism, socialism, and democracy. London: Unwin University Books Press.

65. Sparrowe, R. T., Liden, R. C., 1997. Process and Structure in Leader-Member Exchange. Academy of Management Review. 22(2), pp. 522-55.

66. Spector, P. E., Brannick, M. T., 2011. Methodological urban legends: The misuse of statistical control variables. Organizational Research Methods, 14(2), pp. 287-305.

67. Sternberg, R. J., Lubart, T. I., 1999. The concept of creativity: Prospects and paradigms. Handbook of creativity, 1, pp. 3-15. 495.

68. Sternberg, R. J., Frensch, P. A., 2014. Complex problem solving: Principles and mechanisms. Psychology Press: UK.

69. Stock, J. H. and M. W. Watson(2012): "Disentangling the Channels of the 2007-2009 Recession,” NBER Working Papers 18094, National Bureau of Economic Research, Inc.

70. Treviño, L. K., den Nieuwenboer, N., Kreiner, G. E., Bishop, D., 2014. A grounded theory study of legitimacy work among ethics and compliance officers, Organizational Behavior and Human Decision Processes, 123, pp. 186-205.

71. Treviño L. K., Brown, M., Hartman, L., P., 2003. A qualitative investigation of perceived executive ethical leadership: Perceptions from inside and outside the executive suite. Human Relations, 56(1), pp. 5-37.

72. Tummers, L. G., \& Knies, E. (2013). Leadership and meaningful work in the public sector. Public Administration Review, 73(6), pp. 859-868.

73. Tierney, P., Farmer, S. M., 2011. Creative self-efficacy development and creative performance over time. Journal of Applied Psychology, 96(2), pp. 277-293.

74. Uhl-Bien, M., 2006. Relational Leadership Theory: Exploring the social processes of leadership and organizing. The Leadership Quarterly 17(6), pp. 654-676.

75. Utterback, J. M., 1994. Mastering the Dynamics of Innovation. Harvard Business School Press, Boston, MA.

76. Van Wart, M., Hondeghem, A., Bouckaert, G., Ruebens, S., 2012. Administrative Leadership in the context of governance. In Rome: Paper for the XVI Annual Conference of the International Research Society for Public Management Panel on Leadership in the public sector: back to the future.

77. Walumbwa, F. O., Mayer, D. M.Wang, P., Wang, H., Workman, K., Christensen, A.L., 2011. Linking ethical leadership to employee performance: The roles of leadermember exchange, self-efficacy, and organizational identification. Organizational Behavior and Human Decision Processes, 115 (2), pp. 204-213.

78. Walsh M., Lynch P., Harrington D., 2009. Innovativeness: A Conceptual Framework, Antecedents, Dimensions \& Outcomes, RIKON (Research in 
Innovation, Knowledge \& Organisational Networks) Group). In: EuroCHRie, $22-24^{\text {th }}$ October, Helsinki. Prieiga.

79. Wang, C. L., Ahmed, P. K., 2004. The development and validation of the organizational innovativeness construct using confirmatory factor analysis. European Journal of Innovation Management 7, pp. 303-313. 537.

80. Wang, C. L., Ahmed, P. K., 2007. Dynamic capabilities: A review and research agenda. International Journal of Management Reviews, 9, pp. 31-51.

81. Wayne, S. J., Shore, L. M., Liden, R. C., 1997. Perceived organizational support and leader-member exchange: A social exchange perspective. Academy of Management journal, 40(1), pp. 82-111.

82. Wayne, S. J., Shore, L. M., Bommer, W. H., Tetrick, L. E., 2002. The Role of Fair Treatment and Rewards in Perceptions of Organizational Support and LeaderMember Exchange. Journal of Applied Psychology. 87(3), pp. 590-598.

83. Yu, et al., 2018

84. Yukl, G. A., Gordon, A., Taber, T. 2002. A Hierarchical Taxonomy of Leadership Behavior: Integrating a Half Century of Behavior Research. Journal of Leadership and Organisational Studies.9 (1), pp. 15-32.

85. Yukl, G., O’Donnell, M., Taber, T., 2009. Influence of leader behaviors on the leader-member exchange relationship, Journal of Managerial Psychology, 24(4), pp. 28999. 569.

86. Yukl, G. A., 2013. Leadership in organizations. (8th ed.) Harlow: Pearson Education.

87. Zaltman, G., Duncan, R., Holbek, J., 1973. Innovations and organizations. John Wiley \& Sons. 